\title{
Hubungan Penerapan Strategi Pembelajaran Berbasis Masalah Oleh Guru Geografi pada Materi Bumi dan Jagad Raya dengan Hasil Belajar Siswa Kelas X SMA Negeri 10 Singkawang Tahun Ajaran 2012/2013
}

\author{
Ivan Veriansyah $^{1)}$ \\ STKIP-PGRI Kota Pontianak, Indonesia \\ ivanveriansyah@gmail.com
}

\begin{abstract}
This research aims to know the objective information about (1) the application of problem-based learning strategy about earth and solar system material of tenth grade students of SMA 10 Singkawang (2) students' achievement about earth and solar system material of tenth grade students of SMA 10 Singkawang (3) the correlation between problem based learning strategy about earth and solar system material with the students' achievement of tenth grade students of SMA 10 Singkawang. This research is quantitative research and uses correlation study method. The populations in this research are all the social tenth grade students which consist of 133 students and the samples are 53 students by using random sampling proportional technique. The technique of collecting the data is indirect observations and indirect communication. The tools of data collection are questionnaire and interview sheet. The data analysis technique in this research is using product moment correlation formula. The result of the research shows that (1) the application of problem based learning strategy about earth and solar system material of tenth grade students of SMA 10 Singkawang is "very good" with percentage 90,07\%; (2) the average score of students' achievement about earth and solar system material of tenth grade students of SMA 10 Singkawang is 78,58 and categorize as "good"; (3) there is a significant and positive correlation between problem based learning strategy about earth and solar system material with the students' achievement of tenth grade students of SMA 10 Singkawang and the $r$ is 0,7549 and categorize as "strong".
\end{abstract}

Key words: problem based learning strategy, students' achievement

\section{PENDAHULUAN}

Tujuan utama pendidikan adalah untuk menyiapkan individu-individu yang mampu untuk berpikir, menemukan, dan menciptakan sesuatu yang baru, bisa melihat permasalahan serta menemukan cara pemecahan baru terhadap masalah dapat dipertanggung jawabkan. Pendidikan mempunyai peranan yang sangat penting dalam pengembangan potensi diri dan merupakan cikal bakal dalam pembangunan nasional seseorang.

Pentingnya pendidikan mendesak para praktisi pendidikan untuk terus berinovasi demi meningkatkan mutu pendidikan di Indonesia. Upaya-upaya yang paling sering dilakukan adalah dengan menciptakan inovasi-inovasi yang mampu menumbuhkan motivasi siswa dan mampu mewujudkan tujuan utama proses pembelajaran yaitu mewujudkan siswa yang mampu berpikir kritis, kreatif dan memiliki keterampilan berpikir yang tinggi.

Hasil belajar seringkali dijadikan tolak ukur terhadap pemahaman siswa tentang suatu materi. Hasil belajar yang baik tentu saja menjadi harapan bagi setiap siswa. Bahkan terkadang siswa lebih cenderung fokus terhadap pencapaian nilai yang baik daripada proses pembelajaran itu sendiri. Padahal, hasil belajar yang memuaskan hanya bisa dicapai jika siswa sudah memahami materi dengan baik dan pemahaman itu sendiri hanya bisa didapat jika siswa mengikuti proses pembelajaran dengan sungguh-sungguh.

Ada beberapa upaya yang dapat dilakukan untuk meningkatkan hasil belajar siswa salah satunya adalah dengan menerapkan strategistrategi pembelajaran yang menarik demi meningkatkan motivasi siswa untuk belajar. Selain itu pemilihan strategi yang tepat akan sangat menentukan keberhasilan siswa dalam memahami materi yang sedang diajarkan. Salah satu strategi 
yang sedang popular dikembangkan di dunia pendidikan adalah problem based learning strategy atau strategi pembelajaran berbasis masalah.

Strategi pembelajaran berbasis masalah diyakini bisa menjadi sebuah upaya yang efektif demi meningkatkan pemahaman siswa teruatama pada mata pelajaran geografi. Pembelajaran berbasis masalah merupakan penggunaan berbagai macam kecerdasan yang diperlukan untuk melakukan konfrontasi terhadap tantangan dunia nyata, kemampuan untuk mengetahui segala sesuatu yang baru dan kompleksitas yang ada (Sanjaya :2005).

Meningkatkan motivasi belajar siswa dapat dilakukan dengan cara menyuguhkan isu-isu atau masalah-masalah yang sedang terjadi disekitarnya. Hal ini dapat menjadikan siswa menjadi pelajar yang mandiri karena dapat menggali kreativitas siswa dalam mencari informasi, menemukan informasi, menganalisis informasi dan menyimpulkan informasi tersebut. Jika siswa terlibat secara aktif dalam proses pembelajaran, maka akan lebih mudah bagi siswa tersebut untuk memahami materi yang diajarkan sehingga siswa dapat meraih prestasi belajar yang lebih baik.

Mengingat betapa berpengaruhnya sebuah strategi pembelajaran terhadap hasi belajar siswa, peneliti tertarik untuk meneliti tentang hubungan strategi pembelajaran berbasis masalah oleh guru geografi pada materi bumi dan jagad raya dengan hasil belajar siswa kelas X SMA Negeri 10 Singkawang.

\section{METODE PENELITIAN}

Penelitian ini dilaksanakan di SMA Negeri 10 Kota Singkawang pada bulan Mei 2013. Penelitian ini dilakukan kepada siswa kelas X IPS pada semester 2 dengan jumlah sampel sebanyak 53 siswa atau sebanyak $40 \%$ dari jumlah populasi yang ada.

Penelitian ini merupakan penelitian kuantitatif dengan bentuk penelitian studi korelasi atau studi hubungan. Teknik pengumpulan data menggunakan teknik observasi tidak langsung dengan alat berupa angket penerapan stratgei pembelajaran berbasis masalah dan teknik komunikasi langsung dengan menggunakan alat berupa panduan wawancara.

Adapun analisis data yang dilakukan yaitu analisis data angket dan analisis korelasi product moment. untuk menhitung persentase hasil angket,data yang sudah terkumpul kemudian dianalisis dengan dimasukkan kedalam tabel frekuensi untuk diketahui persentase masingmasing indikator, dengan rumus sebagai berikut :

$p=\frac{f}{N} \times 100 \%$

Keterangan :

$p$ : persentase

$f$ : frekuensi jawaban responden

$\mathrm{N}$ : jumlah sampel penelitian(Sudijono,2010).

Sedangkan untuk perhitungan korelasi Product Moment, data yang diperoleh kemudian dihitung koefisien korelasinya dengan menggunakan rumus korelasi Product Moment, sebagai berikut :

Rxy $=\frac{n(I X Y)-(I X)(I Y)}{\sqrt{\left[n\left(I X^{2}\right)-(I X)^{2}\right]\left[n\left(I N Y^{2}\right)-(I Y)^{2}\right.}}$

Keterangan :

Rxy = Koefisien korelasi product moment

$\mathrm{N} \quad=$ jumlah sampel

$\mathrm{X}=$ nilai angket

Y = nilai hasil belajar (Arikunto, 2002)

\section{HASIL DAN PEMBAHASAN}

Penelitian ini dilakukan sejak bulan Maret-Mei tahun 2013 meliputi tahap perijinan, pelaksanaan, pengumpulan data dan analisis data. Berikut hasil penelitian yang didapat pneliti di lapangan:

1. Penerapan Strategi Pembelajaran Berbasis Masalah oleh Guru Geografi

Tahap awal penelitian untuk mengumpulkan data yang dibutuhkan yaitu menyebarkan angket yang berisi 40 item pertanyaan seputar penerapan strategi pembelajaran oleh guru geografi di kelas. Pertanyaan tersebut dipetakan menjadi 5 aspek pada strategi pembelajaran berbasis masalah dengan total 31 indikator.

Dari hasil pengumpulan data yang didapatkan, ditemukan hasil sebagai berikut: (1) aspek karakteristik strategi pembelajaran berbasis masalah dengan total 16 indikator sebesar $88,91 \%$ 
(2) aspek hakikat strategi pembelajaran berbasis masalah dengan total 3 indikator sebesar 91,9\% (3) aspek tahapan dalam strategi pembelajaran berbasis masalah dengan total 5 indikator sebesar 90,94\% (4) aspek ranah penilaian kognitif dengan total 6 indikator sebesar 93,55\% (5) aspek ranah penilaian afektif dengan total 1 indikator sebesar $85,84 \%$. Peneliti kemudian menghitung rata-rata dari perhitungan di atas sehingga didapatlah hasil bahwa presentase penerapan strategi pembelajaran berbasis masalah sebesar 90,07\% dengan kategori "sangat baik".

Hasil ini menunjukkan bahwa guru geografi kelas X yaitu ibu Berti Dwi Sartika, S.Pd telah menerapkan strategi pembelajaran berbasis msalah dengan sangat baik dengan memperhatikan setiap aspek dan indikator dari strategi itu sendiri. Brown (2004) menyatakan "the teacher plays major role in designing classroom activity". Artinya guru memiliki peranan yang penting dalam mendesain aktivitas di kelas. Oleh sebab itu, peranan guru sangatlah dibutuhkan dalam menciptakan strategi-strategi yang inovatif dalam proses pembelajaran.

Pada dasarnya penerapan strategi yang tepat dapat menunjang pemahaman siswa terhadap sebuah materi pelajaran. Selain meningkatkan motivasi, strategi yang menarik juga dapat meningkatkan keefektifan proses pembelajaran sehingga tujuan utama pembelajaran dapat tercapai.

\section{Pada hakikatnya SPBM (Strategi}

Pembelajaran Berbasis Masalah) berkaitan dengan penggunaan intelegensi dari dalam individu yang berada dalam sebuah kelompok atau lingkungan untuk memecahkan masalah yang bermakna relevan dan kontekstual. Hasil pendidikan yang diharapkan meliputi pola kompetensi dan intelegensi yang dibutuhkan untuk berkiprah pada abad ke21. Suksesnya pelaksanaan SPBM sangat bergantung pada seleksi, desain dan pengembangan masalah. Hal pertama yang harus diketahui adalah tujuan dari SPBM itu sendiri yaitu penguasaan isi belajar dari disiplin heuristic dan pengembangan keterampilan pemecahan masalah. SPBM juga berhubungan dengan belajar tentang keidupan luas (lifewide learning), keterampilan memaknai informasi, kolaboratif dan belajar tim, dan keterampilan berpikir reflektif dan evaluatif.

Mediator yang efektif membantu para siswa untuk menemukan signifikansi dari bekerja memecahkan masalah dan menjadika proses SPBM itu mempunyai manfaat guna tercapainya tujuan pembelajaran berbasis masalah. SPBM memiliki nilai positif yaitu dapat menumbuhkan tradisi intelektual. Hal ini hanya dapat ditempuh dengan membiasakan siswa untuk berpikir secara bebas dan kreatif. Siswa harus dilatih untuk memecahkan masalah yang berbasis rasional agar siswa terlatih untuk sigap dalam menghadapi masalah di dalam kehidupan sehari-hari. SPBM juga dapat melatih siswa untuk berani dalam mengambil keputusan dan kesimpulan terhadap sebuah masalah. Keputusan adalah kegiatan akal budi yang mengakui atau mengingkari suatu realita atau masalah.

2. Hasil Belajar Siswa pada Materi Bumi dan Jagad Raya

Pengumpulan data hasil belajar siswa diambil dari nilai yang sudah di dapat oleh guru Geografi tentang materi bumi dan jagad raya dengan melakukan formatif tes. Tes terdiri dari 20 pertanyaan seputar materi bumi dan jagad raya. Dari hasil pengumpulan data, diketahui hasil belajar siswa kelas X dikategorikan ke dalam 2 golongan yaitu baik dan sangat baik. Terdapat 21 siswa memiliki nilai dengan rentang 70-79 dengan kategori "baik" atau sebanyak 39,6\%. Terdapat 32 siswa memiliki nilai dengan rentang 80-100 dengan kategori "sangat baik" atau sebanyak $60,4 \%$.

Hasil belajar menurut Sudjana (2001:22) adalah "kemampuan yang dimiliki siswa setelah ia menerima pengalaman belajarnya". Selanjutnya Sudjana juga mengungkapkan bahwa proses belajar yang optimal memiliki ciri-ciri sebagai berikut: (1) kepuasan dan kebanggan yang dapat menumbuhkan motivasi belajar instrinsik siswa; (2) menambah keyakinan dan kemamuan dirinya, artinya ia tahu kemampuan dirinya dan percaya bahwa ia mempunyai potensi yang tidak kalah dari orang lain apabila ia berusaha; (3) hasil belajar yang dicapai bermakna bagi dirinya seperti akan 
diingat dalam jangka waktu yang lama, dapat mengubah perilaku, bermanfaat untuk mempelajari aspek lain, kemauan dan kemampuan untuk belajar sendiri dan mengembangkan kreativitasnya; (4)hasil belajar yang diperoleh secara menyeluruh mencakup ranah kognitif, afektif dan psikomotorik;(5) kemampuan siswa untuk meilai dan mengendalikan diridalam menilai hasil yang dicapainya; (6) mampu membuat siswa meraih hasil belajar yang sudah ditetapkan atau melebihinya.

"Belajar berbasis keterampilan berpikir merupakan dasar untuk mencapai tujuan belajar bagaimana belajar” (Santyasa:2009). Desain pembelajaran yang konsisten dengan tujuan belajar yang disasar tersebut tentunya diupayakan pula untuk mencapai hasil belajar sesuai dengan yang diharapkan.

3. Hubungan antara Penerapan Strategi Pembelajaran Berbasis Masalah oleh Guru Geografi dengan Hasil Belajar Siswa

Setelah data kedua variabel terkumpul, peneliti menganalisis data dengan menggunakan rumus korelasi product moment. Dari hasil perhitungan diketahui bahwa nilai $r$ sebesar 0,7459, sehingga $r_{\text {hitung }}>r_{\text {tabel }}$ yaitu $0,7459>$ 0,279 . Sehingga dapat disimpulkan bahwa terdapat hubungan yang positif dan signifikan antara penerapan strategi pembelajaran berbasis masalah oleh guru Geografi pada materi bumi dan jagad raya dengan hasil belajar siswa kelas X SMA N 10 Singkawang Tahun Ajaran 2012/2013. Hasil perhitungan nya dapat juga dilihat pada siagram di bawah ini :

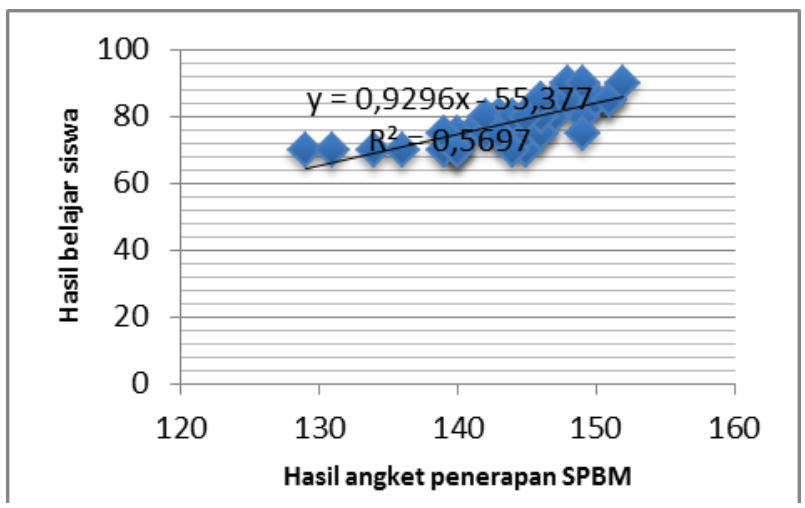

Hubungan penerapan SPMB terhadap Hasil Belajar Siswa
Hasil belajar merupakan aspek penting dalam penggunaan strategi pembelajaran karena sebagai tolak ukur keberhasilan atau kegegalan strategi tersebut. Begitu juga sebaliknya, penggunaan strategi pembelajaran juga sangat menentukan hasil belajar siswa. Merujuk kepada hasil penelitian yang menunjukkan bahwa penerapan SPBM memiliki hubungan yang positif dan signifikan terhadap hasil belajar siswa kelas X dengan kategori kuat, maka sangat disarankan kepada guru geografi untuk bisa menggunakan dan lebih mengembangkan penerapan SPBM di kelas.

Manfaat dari penerapa SPBM adalah untuk membantu siswa untuk memahami suatu materi yang diajarkan dengan cara menyuguhkan sebuah masalah kepada siswa dan kemudian meminta siswa untuk mencari informasi, menemukan infomasi, menganalisa kemudian menyimpulkan. Strategi ini juga berfungsi untuk membatasi ruag lingkup pemikiran siswa. Dengan kata lain, siswa tidak perlu memikirkan seluruh aspek geografi namun hanya focus terhadap masalah yang disuguhkan oleh guru dengan pemahaman yang mendalam dan detail.

Dengan lebih aktifnya siswa dan terlibat langsung dalam kegiatan pembelajaran, tentu akan sangat membantu dalam pemahaman siswa terhadap materi yang diajarkan. Pemahaman yang baik tentu dapat menunjang hasil belajar yang diharapkan. Dengan begini dapatlah kita simpulkan bahwa SPBM (Strategi Pembelajaran Berbasis Masalah) adalah strategi yang sangat efektif dalam rangka meningkatkan hasil belajar siswa pada materi bumi dan jagad raya siswa kelas $\mathrm{X}$ SMA Negeri 10 Singkawang tahun ajaran 2012/2013.

\section{KESIMPULAN}

Dari hasil penelitian yang telah dijabarkan di atas, dapat ditarik kesimpulan sebagai berikut :

1. Penerapan strategi pembelajaran berbasis masalah oleh guru geografi dikategorikan 
"sangat baik" dengan persentase sebesar $90,07 \%$.

2. Hasil belajar siswa kelas X SMA Negeri 10 Singkawang tahun ajaran 2012/2013 pada materi bumi dan jagad raya dikategorikan "baik" dengan rata-rata nilai 78,58.

3. Terdapat hubungan yang hubungan yang positif dan signifikan antara penerapan strategi pembelajaran berbasis masalah oleh guru Geografi dengan hasi belajar siswa pada materi bumi dan jagad raya siswa kelas $X$ SMA N 10 Singkawang Tahun Ajaran 2012/2013. Hal ini dapat dilihat dari hasil perhitungan korelasi yaitu nilai $\mathrm{r}_{\text {hitung }}>\mathrm{r}_{\text {tabel }}$ atau $0,7459>0,279$ sehingga dikategprikan "kuat".

\section{DAFTAR PUSTAKA}

[1] Sanjaya,Wina. (2005). Pembelajaran Dalam Implementasi Kurikulum Berbasis Kompetensi. Jakarta: Kencana, Prenada Media Group.

[2] Sudijono. (2010) Pengantar Evaluasi Pendidikan. Jakarta: Rajawali Press.

[3] Sudjana, N. (2001). Penilaian Hasil Proses Belajar Mengajar. Rosdakarya Bandung. 